Article

\title{
Youth Ministry after the Synod on Young People- Ten Points of No Return
}

\section{Rossano Sala}

Faculty of Theology, Institute of Pastoral Theology, Pontifical Salesian University, 1, 00139 Rome, Italy; sala@unisal.it

Received: 4 June 2020; Accepted: 23 June 2020; Published: 25 June 2020

\begin{abstract}
From October 2016 to March 2019, the Catholic Church engaged in a lengthy journey together with young people. Over these two and a half years, some important documents were produced, including the Post-Synodal Apostolic Exhortation Christus Vivit by Pope Francis. The Synod on Youth has involved the entire Catholic Church, mobilizing all Church communities around the world. After explaining the identity and meaning of a Synod for the Catholic Church, the author offers ten points of no return, which are to be considered the main fruits of this journey. They are leaven for the renewal of youth ministry in the Catholic context and elements for further exploration, comparison and dialogue with other Christian denominations.
\end{abstract}

Keywords: young people; Synod; Catholic Church; youth and young adult ministry; Pope Francis; vocation; discernment; Synodality

\section{Introduction}

1. On 17 September 1965, through the "Motu Proprio" Apostolica Sollicitudo, Pope Paul VI instituted in the Catholic Church the Synod of Bishops to accompany the process of reception of the Second Vatican Council (1962-1965) (cf. Pope Paul VI 1965). Up until now, fifteen Ordinary General Assemblies, three Extraordinary Assemblies and eleven Special Assemblies have been held. From a normative point of view, the organization and conduct of the Synod depends on the Apostolic Constitution Episcopalis Communio, promulgated by Pope Francis on 15 September 2018 (cf. Pope Francis 2018).

2. I had the honor of participating in the Fifteenth Ordinary General Assembly of the Synod of Bishops on the theme: "Young People, the Faith and Vocational Discernment." After extensive consultation, Pope Francis called this Synod on 6 October 2016. The Synod's journey ended on 25 March 2019, with the publication of the Post-Synodal Apostolic Exhortation Christus Vivit. It was, therefore, a long and articulated process that lasted about two and a half years. It was not an isolated event that occurred by chance.

I have served in the General Secretariat of the Synod of Bishops (the permanent body of the Holy See that accompanies all synodal processes) since the convocation of the Synod on Youth. First, as an expert and then, from 17 November 2017, as "Special Secretary" together with Fr. Giacomo Costa SJ. I was, therefore, able to be present from within throughout the synodal process, offering my expertise as a researcher in the field of youth ministry gained at the Salesian Pontifical University.

3. Here I offer the reader an overview, first of all, of what took place through the various events that occurred and the documents that were produced during the synodal process.

The first important document was the Preparatory Document (published on 13 March 2017), which had the task of "advising on the synodal theme" and above all, offered a "Questionnaire" intended primarily for the 114 Episcopal Conferences around the world, to open the phase of consultation with the whole People of God (XV Ordinary General Assembly of the Synod of Bishops 2017). The meaning of the term "young people" or "youth" was made clear in this document: "The word 
youth refers to persons who are roughly 16 to 29 years old, while bearing in mind that the term needs to be adapted to local circumstances. In any case, it is good to remember that the term youth, in addition to referring to persons, is a stage of life that each generation understands in an unequal, original manner" (XV Ordinary General Assembly of the Synod of Bishops 2017, I). This clarification also applies to this article.

From the beginning, there has been a desire to involve young people from all over the world. This has been done, worldwide, through three initiatives. The first was the administration of the Online Questionnaire to young people around the world (June-December 2017), to which about 220,000 young people responded (XV Ordinary General Assembly of the Synod of Bishops 2018a). There was also an International Seminar on the Situation of Young People (11-15 September 2017) which brought together about 50 scholars at international level and about thirty young people (cf. Baldisseri 2018). The third and most important initiative was the Pre-Synodal Youth Meeting (19-24 March 2018), which was attended by about 300 young representatives from all the Episcopal Conferences around the world and which, after a week of work together, produced a very significant summary document (XV Ordinary General Assembly of the Synod of Bishops 2018b).

The result of these three events, together with the responses of the Episcopal Conferences and together with about 3000 "contributions" that came directly to the Secretariat of the Synod, were the five sources used to write the Instrumentum Laboris, a Latin title meaning: working document (XV Ordinary General Assembly of the Synod of Bishops 2018d). This document, published on 19 June 2018, and comprising 214 numbered articles, was an ordered and concise collection of all the material received during the listening phase and had the task of preparing the central moment of the Synod, namely the Synodal Assembly.

This Assembly, held from 3 to 28 October 2018, in the Vatican, was attended by 267 Synod Fathers with voting rights, 8 fraternal delegates belonging to different Christian denominations, 23 experts and 49 listeners, including 34 young people from different cultures and geographical areas. The work of this Synodal Assembly took place partly in plenary meetings and partly in the 14 smaller language groups (four English-speaking, three French-speaking, three Italian-speaking, two Spanish-speaking, one Portuguese- and one German-speaking). At the end, a Final Document comprising of 167 numbered articles was produced and gained a majority vote (XV Ordinary General Assembly of the Synod of Bishops 2018c). It was intended primarily for the Holy Father Pope Francis. He immediately decided it be published in its entirety and be voted on number by number.

The last step comes after the Synod Assembly had completed its deliberations and had the Holy Father as its author. It is, in a certain sense, the mature fruit of this journey. It is the post-synodal Apostolic Exhortation Christus Vivit, signed by Pope Francis on 25 March 2019, in the Marian shrine of Loreto, Italy (Pope Francis 2019). It is a document comprising 299 numbered articles and takes into account the entire synodal journey, but at the same time relaunches it in a new way.

4. It would be impossible for me to be thinking of merely offering a summary of all this, because what emerges from the Synod will need a long time in order to be studied at a scientific level, understood in all its prophetic content, and to bear the fruits (cf. Sala 2020).

The aim of this article is much more modest. Bearing in mind the main documents of the Synod (all of which are easily available in different languages on the following three official sites: www.synod.va---www.synod2018.va—http://www.vatican.va/roman_curia/synod/index.htm) and the personal experience I have gained over the last four years, I am offering the reader, in summary form, ten points of no return so we can think, plan and exercise youth and young adult ministry today in a new way. The conviction that guides me is this: after the Synod there are some "fixed points" from which there is no turning back without betraying the expectations of God that have been heard through the presence and the word of young people.

5. A final small but important introductory note is necessary. None of the following ten points directly focuses on the theme of "accompaniment." In fact, I am convinced that accompaniment is the theme that runs through the entire synodal journey. That is why I think that each of the ten points that follow 
speaks about accompaniment from a different point of view, given that the idea of accompaniment is very difficult to define, because "Accompaniment can be said in many ways" (XV Ordinary General Assembly of the Synod of Bishops 2018d, nos. 121-29), although it is worth remembering that "the origin of the term accompany points to bread broken and shared (cum pane), with all the symbolic human and sacramental richness to which it refers" (XV Ordinary General Assembly of the Synod of Bishops 2018c, no. 92).

If we look carefully, this is also the choice made by Pope Francis: none of the nine chapters of Christus Vivit is dedicated directly to the theme of accompaniment, for the simple reason that the entire Apostolic Exhortation deals in various ways with this decisive theme for the Church today. Accompaniment is the keyword that sums things up and urges us to a new ecclesial style of closeness to the younger generations.

\section{Presence: The Existence of Young People is an Appeal from God}

The conviction that reality is more important than the idea remains one of the fixed points of Pope Francis' pontificate. We must start from reality as it is, and first of all, listen to the times in which we live.

During the synodal journey, the inter-generational dialogue was very instructive. The bishops and other adults, during the Synodal Assembly, engaged with the young people. While the former tended to speak of "youth" as a theoretical and abstract category, the latter always referred to their life experience. Here is the first conviction: "Youth is not an object that can be analyzed in abstract terms. In reality, 'youth' does not exist-there exist only young people, each with the reality of his or her own life" (Pope Francis 2019, no. 71). The Synod Fathers together affirmed with certainty that "even today God speaks to the Church and to the world through the young, their creativity and their commitment, as well as their sufferings and their pleas for help. With them we can read our era more prophetically and recognize the signs of the times" (XV Ordinary General Assembly of the Synod of Bishops 2018c, no. 64).

From the abovementioned comes a primacy of listening attentively to the lives of the young, because it is there that God makes himself present, and the life of young people, therefore, is a "theological place." They are immersed, together with all of us, in an era of great change. We live at a time of "metamorphosis": young people have told us in a thousand ways that the digitization of the world and the environmental emergency, the new understanding of our body and sexuality, the exponential growth of pluralism in all fields and the speeding up of every process, all situate us within a great complexity that is impossible to control.

The world is now a small village where we must learn to live together. This can lead to confusion, inflexibility and closing ourselves off from others. However, it could also lead us toward new styles of solidarity and communion. Certainly, this process makes us rediscover human weakness and the need for help.

\section{Frailty: The Young Need Tenderness and Want Reconciliation}

The context described above makes all positions fragile. During the Synod's journey, the great and sad reality of the mental illnesses of young people, of their existential discomfort, emerged. Depression and suicide, signs of a lack of meaning and sometimes, a consequence of the lack of welcome and listening on the part of the Church and society, have made us aware that there is great weakness and frailty in the younger generations, and especially, in those who appear invincible and violent.

We must come to terms with frailty and failure. We are not omnipotent! This awareness can be a great opportunity for all young people: that of recognizing once more that they are human, of once more coming into contact with our finite nature, "in the sure knowledge that error, failure and crisis are experiences that can strengthen their humanity" (Pope Francis 2019, no. 233). For this reason, frailty, failure and falls are life experiences that need to be accompanied by gentleness. 
The young people have asked us, pastorally speaking, for greater closeness. Closeness, tenderness, gentleness, and consolation are words that echo through many of the Synod's passages. If we want to go deeper, we find in the heart of every young person a great desire for reconciliation.

Everyone at the Synod was struck by the humble and prophetic presence of Brother Alois, prior of the monastic community of Taizé. This experience came about through a clearly ecumenical intention, that is, to create a platform for listening, forgiveness and dialogue between the different Christian denominations. Then it became, little by little, a place that is frequented especially by young people. Why? Because young people seek unity, peace and joy!

\section{Searching: Young People Showed They Were always Open and Available}

We lack fixed points today. Change and fragility set us on a quest, a journey. This is a great opportunity for our ministry with young people. Throughout the synodal journey, there was no sense of a preconceived closure towards the world of faith and the reality of the Church, but a "healthy restlessness typical of youth [that] continues to dwell in every heart that remains young, open, and generous. True inner peace coexists with that profound discontent. As Saint Augustine said: "You have created us for yourself, Lord, and our hearts are restless until they find their rest in you" (Pope Francis 2019, no. 138). The healthy restlessness of young people, a sign of their openness to God, is a great pastoral opportunity.

Young people have shown themselves to be open to exchange, respectful of different positions, open to dialogue and others' reasoning. Ours was an atmosphere of genuine quest and search. The keywords, to myself, have been "openness" and "availability." At an ecclesial level, priests and bishops have much to learn about this because sometimes they show themselves to be as rigid as the Pharisees, incapable of really giving the floor to others, and closed to listening to different positions. Sometimes, bishops and priests have a very monolithic and not very symphonic concept of truth.

Jesus in the Gospels reveals himself to be a great companion of people who are searching. He has the temperament to ask the right questions at the right time, he knows to wait for the right time, and he stands by young people patiently without judging. He really has authority, in the true sense of the term, because "In its etymological meaning, auctoritas indicates the capacity for enabling growth; it does not express the idea of a directive power, but of a real generative force" (XV Ordinary General Assembly of the Synod of Bishops 2018c, no. 71).

\section{Discernment: We Are all Called to Examine Ourselves}

Searching is not an end in itself, but has, by its very nature, the desire to find. The restlessness of the heart that sets us in motion is generated by a search for fullness which takes the path of life. It is an arduous path, full of obstacles, where recognizing the right life is not automatic. Temptation, evil and sin can easily find a place. There is great difference between light and being dazzled by it, yet sometimes they can be confused. It is sometimes hard to distinguish between truth and error; it is very difficult to judge between good and evil; one can be deceived between the living God and the many idols who try to imitate him (cf. Pope Francis 2013, no. 51).

The abovementioned is why one of the great words of the Synod's journey was "discernment." This is the right attitude to have in times of great confusion. It is the attitude that goes to the root of things and thus avoids being deceived by appearances. It is the style capable of distinguishing between the superfluous and the essential, between the useless and the necessary. Discernment means not having the immediate solution at hand, but seeking what God urges us to be, because "Discernment leads us to recognize-and become attuned with —-the action of the Spirit, in true spiritual obedience" (XV Ordinary General Assembly of the Synod of Bishops 2018d, no. 2).

The entire Synod's journey was set up, methodologically, as a communal journey of discernment marked by three stages: recognizing, interpreting, and choosing. Both the Instrumentum Laboris and the Final Document are structured around these three verbs. To recognize is to look and listen: it is a matter of understanding not only intellectually but, above all, with a heart capable of evangelical compassion. 
To interpret is to reflect further on what has been recognized, using criteria of interpretation and evaluation: it is a matter of seeking the causes with truth and honesty and giving the reasons for what we have found. Only after these two steps can we move towards prophetic and courageous choices for the future that will enable us to follow the Spirit.

\section{Proclamation: We Are Called to Share the Joy of the Gospel}

When one discerns according to the Spirit, we said, one arrives at the essential. At the end of the Synod's journey, Pope Francis grasped the essential of faith: "Putting all else aside, I now wish to speak to young people about what is essential, the one thing we should never keep quiet about. It is a message containing three great truths that all of us need constantly to keep hearing" (Pope Francis 2019, no. 111). What are these three great truths? First, "God loves you." Second, "Christ, out of love, sacrificed himself completely in order to save you." Third, "He is alive!" This is the first and only important proclamation, expressed in direct form. All of Chapter 4 of Christus Vivit (Pope Francis 2019, nos. 111-33) clearly proclaims these three truths to all young people.

Young people need truth, they are seekers of truth, and through discernment they must come into contact with truth. They are not content with surrogates for truth. They have a right to hear Jesus Christ proclaimed as the way, the truth, and the life (cf. Jn 14:6).

It is clear that this perspective, to tell the truth a very ecumenical one, appears to be the logical consequence of the kerygmatic and missionary turning point that Pope Francis is impressing on the Catholic Church. There is no freedom without truth, and there is neither freedom nor truth without listening to the Word and following the Lord: "If you continue in my word, you are truly my disciples; and you will know the truth, and the truth will make you free" (Jn 8:31-32).

\section{Spirituality: Young People Need to be Accompanied towards a Solid Friendship with Jesus}

At the heart of Christus Vivit lies a formidable question: "What does it mean to live the years of our youth in the transforming light of the Gospel?" (Pope Francis 2019, no. 134). It puts the issue of Christian life and spirituality in terms of a question.

We talked a lot about spirituality at the Synod. We were asked by young people about the quality of our liturgy, which many of them consider the first school of faith. They told us, somewhat provocatively, that "Christians profess a living God, but some attend Masses or belong to communities which seem dead" (XV Ordinary General Assembly of the Synod of Bishops 2018d, no. 187). They challenged our youth ministry, which is often played out in terms of great activity and very noisy events, by proposing much more important themes: silence, prayer and contemplation, showing respect for and attraction to the contemplative life. In a world dominated by uninterrupted media bombardment, they ask us to accompany them through quality spiritual experiences, to help them enjoy personal friendship with Jesus, the affection of faith, and deep contact with the Word of God.

To enter into paths of spirituality means to rediscover "the way of beauty" in youth ministry, opening up glimmers of transcendence in a world that too often pushes us to close ourselves within a framework of immanent meaning. Beauty is synonymous with holiness: "The young need saints who can form other saints, thus showing that 'holiness is the most attractive face of the Church'" (XV Ordinary General Assembly of the Synod of Bishops 2018c, no. 166).

\section{Family: Let's Move towards a Church with a Familiar Face and Style}

At a time when young people find themselves in a situation of uncertainty and prone to error, and even being orphans in spiritual terms, the Christian community is called to become more "adoptive" in their regard (Eph 3:14-15; In 1:12). The emphasis is thus placed on the generative capacity of the Church, which is conceived of in terms of a family paradigm capable of abandoning an individualistic style of youth ministry in order to assume a more communitarian one, "characterized by a family atmosphere built on trust and confidence" (XV Ordinary General Assembly of the Synod of Bishops 2018c, no. 138). Thus the Church becomes a welcoming home for all young people, with no one excluded. 
During discussion at the Synod, often the Church as a whole was asked to move from the primacy of structures to one of relationships, from the centrality of bureaucracy to that of bonds. There is, in this historical moment, at least in the secularized West, a great "desire for community" that the younger generations express through various requests, because "communal experiences are still essential for young people if, on the one hand, they are allergic to institutions. It is equally true that they are also looking for meaningful relationships within true communities and personal contact with shining and consistent witnesses" (XV Ordinary General Assembly of the Synod of Bishops 2018d, no. 175). They ask that the Church should increasingly have a familiar face, where everyone feels called by name and welcomed at the point where his or her freedom is found, without any prior judgment.

Many young people, especially those who grew up in a situation of "family poverty," have shown great sensitivity toward the family and a great desire for family. If indeed, for all of us "you have received a spirit of adoption" (Rom 8:15), we must commit ourselves so that the Church may truly be one great family!

\section{Voluntary Work: The Royal Way of Charity and Responsible Service}

Of course, the Church is called to assume a familiar face, but not a closed one. There is strong inflexibility in many forms of multi-communalism today as communities stand side by side without contaminating each other, without coming into contact, without meaningful relationships, without any exchange of gifts.

During all the various phases of the Synod, there was an insistent drive to be and remain an "outgoing Church." This starts from the conviction that Christians are truly themselves only when they come out of themselves and go out to meet others, whoever they may encounter. This is the "ecstatic" identity of the Christian, very well expressed by Pope Francis when he addresses these words to every young person: "How wonderful it would be to experience this 'ecstasy' of coming out of ourselves and seeking the good of others, even to the sacrifice of our lives" (Pope Francis 2019, no. 163).

This position reflects one of the great phenomena of our time, which sees young people as very much proactive with volunteering, charitable commitment, and service to the least and poorest. We have had many moving testimonies from young people who have encountered the faith through service and contact with the Church, which is opposed in fact and in truth through diakonia to the culture of exclusion and discarding people.

It is precisely here that two great polarities that characterized the Synod's journey meet: generous service and vocational discernment. There is a mutual inclusion: the school of service is suitable for discerning vocation, precisely because it speaks through the voice and face of the little ones and the poor. Indeed, it identifies with them, because "just as you did it to one of the least of these who are members of my family, you did it to me" (Mt 25:40).

\section{Vocation: Young People Are Loved Personally and Called by God by Name}

The theme of the Synod, as we accepted it at the beginning, seemed problematic to us: "Young People, the Faith and Vocational Discernment." We asked ourselves: is this theme, put this way, a short-circuit or a prophecy? It asks us to take care of all young people and, at the same time, pushes us toward vocational discernment. In the shared ecclesial imagination, at least in the Catholic one, when we speak of "vocation" we refer almost exclusively to the "vocations of special consecration" (ordained ministry and consecrated life), almost always excluding married life and the world of work. In this regard, it is very interesting to note that Pope Francis, in chapter 8 of Christus Vivit-the one dedicated to the theme of vocation - focuses in a broad and specific way on lay vocations, rehabilitating them in a new and convincing way (Pope Francis 2019, nos. 259-73). We must return to the idea that the lay vocation is the "mother vocation" of all other vocations!

We discovered during the various moments of the Synod that at the basis of human and Christian identity lies the fact of being loved and called. We saw that the vocational question is the great question of identity and that vocation is immediately the giving of a meaning and a destination to existence. 
Hence, we were told that "the great question" that every young person has to ask him or herself is "For whom am I?" (cf. XV Ordinary General Assembly of the Synod of Bishops 2018c, no. 69; Pope Francis 2019, no. 286). This really concerns all young people, no one excluded!

The vocational dimension of youth ministry is more decisive than ever today. I am convinced that youth ministry will not live up to its calling if it does not accompany every young person with a view to the discovery and acceptance of his or her personal vocation. To enter into the world of one's vocation means to grasp the profound meaning of one's existence, thus helping each young person to make contact with the great reality for which "I am a mission on this earth; that is the reason why I am here in this world" (Pope Francis 2019, no. 254).

\section{Synodality: A New and Exciting Path for the Catholic Church}

Last but not least, we arrive at the great theme of Synodality. The unity expressed above between vocation and mission is clearly oriented toward communion. I must say that the journey of this Synod has given us a great surprise, which at the beginning was not even imaginable, but which emerged during the Synodal Assembly as a shared and welcome inspiration.

In the Instrumentum Laboris, the fundamental question was asked: What form of the Church was appropriate for the youth of today? It was an open question to which no one had given a clear answer. The broad indications always leaned in the direction of "doing something" for young people, among the list of different priorities for action. Many, especially among the Synod Fathers from Latin America, were pushing for the Church to make a "preferential option for the young," in the style of their "preferential option for the poor."

However, the young peoples' own words caught us by surprise. They did not ask us, first of all, to do something for them, but first of all, they asked us to set out with them! They invited us to a real conversion from "doing for" to "being with." This is a Copernican revolution!

The young people have been heard. Not only because in the Synod's Final Document, this request of theirs was taken seriously and widely developed (cf. XV Ordinary General Assembly of the Synod of Bishops 2018c, nos. 114-27), but also because we discovered that this is God's great desire for the Church: "It is precisely this path of synodality which God expects of the Church of the third millennium" (XV Ordinary General Assembly of the Synod of Bishops 2018c, no. 118). God and young people are united by a great common desire: they are longing the Church to take on an ever more synodal form.

For these reasons, listening to the inspirations of God and those of the young people, Pope Francis chose as the theme for the next Ordinary General Assembly of the Synod of Bishops-still in the preparation phase and to be held in October 2022-precisely the topic of Synodality: "For a Synodal Church: Communion, Participation, and Mission." This title is truly programmatic: it starts from Communion, the root of Christian life; passes through Participation, where communion is concretely achieved; and arrives at the Mission, which is the great call to share the joy of the Gospel with all young people and with all men and women, no one excluded.

I am convinced that fidelity to this great inspiration will bring undoubted progress, first of all in the ecumenical and inter-religious sphere. Perhaps it is precisely youth ministry-which "has to be synodal" (Pope Francis 2019, no. 206) — that should advance without delay in this direction, opening new paths for the good of all.

\section{Conclusions}

I have proposed "ten points of no return" for doing youth ministry, following the Synod on Youth. In my opinion, it is no longer possible to plan youth ministry in the Catholic sphere without taking these points into consideration, both individually and as a whole. I have described them as points of no return because they are the result of a discernment by the Church that lasted a good three years and that involved the entire Universal Church. To not start out afresh from here would mean betraying the Church and, in some respects, placing oneself outside of her. 
The abovementioned is just as true for teachers of pastoral theology and youth ministry, be they Catholic or from other Christian Denominations. The Synod's documents need to be read, studied, explored more deeply, and disseminated. They also need to be critiqued where needed, to advance reflection. However, dealing with them is something that cannot be avoided, precisely because they represent the "official" point of view of the Catholic Church regarding youth ministry at the beginning of the Third Millennium. And this is really a point of no return!

It seems, to myself, that, as a whole, these ten points offer us an innovative style of Church, one that keeps together the integrity of the Christian proclamation and the gradual nature of its proposal. Indeed, I am convinced that youth ministry will be able to prosper only if evangelization and education are thought of in terms of mutual inclusion, since today, more than ever before, we are called to educate by evangelizing and to evangelize by educating (cf. Sala 2017). The time of separation is over; as soon as possible and in the best possible way, we must regain an integrated unity of all ten points offered.

We are called to embrace a notion of Church and ministry that needs rethinking in terms of the dynamic and complex form of the "polyhedron." Indeed, as Pope Francis puts it, "Here our model is not the sphere, which is no greater than its parts, where every point is equidistant from the center, and there are no differences between them. Instead, it is the polyhedron, which reflects the convergence of all its parts, each of which preserves its distinctiveness" (Pope Francis 2013, no. 236). The polyhedron, made up of various parts that can never be reduced to one another, cannot be simplified but must be taken up in all its rich internal diversity.

The abovementioned is even more true for youth ministry, which must also be conceived of and carried out in a multifaceted way: not, therefore, within a complete, perfect, rational and manageable scheme, but starting from a dynamic that is always open to the action of the Holy Spirit who is the authentic protagonist of the Church's pastoral mission. Moreover, as we know, the Spirit of the Lord surprises us every time: He does not create unity by homogenizing us, but urges us to integrate our differences and thus enter into that mystery of communion which is God himself.

Funding: This research received no external funding.

Conflicts of Interest: The authors declare no conflict of interest.

\section{References}

\section{Primary Sources}

(Scripture Quotations from NRSV (New Revised Standard Version of the Bible) 1989) Scripture Quotations from NRSV (New Revised Standard Version of the Bible), Copyright (C) 2020, by the Division of Christian Education of the National Council of the Churches of Christ in the United States of America, New York: American bible society.

\section{Secondary Sources}

Baldisseri, Lorenzo, ed. 2018. La Condizione dei Giovani Oggi. Atti del Seminario Internazionale di Studio Organizzato Dalla Segreteria Generale del Sinodo dei Vescovi in Preparazione alla XV Assemblea Generale Ordinaria (Città del Vaticano, 11-15 settembre 2017) [The Condition of Young People Today. Acts of the International Study Seminar Organized by the General Secretariat of the Synod of Bishops in Preparation for the XV Ordinary General Assembly (Vatican City, 11-15 September 2017)]. Città del Vaticano: Libreria Editrice Vaticana.

Pope Francis. 2013. Apostolic Exhortation Evangelii Gaudium (24 November 2013). Available online: http://www.vatican.va/content/francesco/en/apost_exhortations/documents/papa-francesco_esortazioneap_20131124_evangelii-gaudium.html (accessed on 31 May 2020).

Pope Francis. 2018. Apostolic Constitution Episcopalis Communio (15 September 2018). Available online: http://w2.vatican.va/content/francesco/en/apost_constitutions/documents/papa-francesco_ costituzione-ap_20180915_episcopalis-communio.html (accessed on 31 May 2020). 
Pope Francis. 2019. Post-Synodal Apostolic Exhortation Christus Vivit (25 March 2019). Available online: http://www.vatican.va/content/francesco/en/apost_exhortations/documents/papafrancesco_esortazione-ap_20190325_christus-vivit.html (accessed on 31 May 2020).

Pope Paul VI. 1965. "Motu Proprio" Apostolica Sollicitudo Establishing the Synod of Bishops for the Universal Church (15 September 1965). Available online: http://www.vatican.va/content/paul-vi/en/motu_proprio/ documents/hf_p-vi_motu-proprio_19650915_apostolica-sollicitudo.html (accessed on 31 May 2020).

Sala, Rossano. 2017. Pastorale Giovanile 1. Evangelizzazione e Educazione dei Giovani. Un Percorso Teorico-pratico [Youth Ministry 1. Evangelization and Education of Young People. A Theoretical and Practical Journey]. Roma: Libreria Ateneo Salesiano.

Sala, Rossano. 2020. Pastorale Giovanile 2. Intorno al Fuoco vivo del Sinodo. Educare Ancora alla vita Buona del Vangelo [Youth Ministry 2. Around the Living Fire of the Synod. Continuing to Educate to the Good Life of the Gospel]. Torino: ElleDiCi.

XV Ordinary General Assembly of the Synod of Bishops. 2017. Preparatory Document (13 January 2017). Available online: http:/press.vatican.va/content/salastampa/it/bollettino/pubblico/2017/01/13/0021/00050.html\#EN (accessed on 31 May 2020).

XV Ordinary General Assembly of the Synod of Bishops. 2018a. Il Mondo Delle nuove Generazioni Attraverso il Questionario on line - The World of New Generations According to the Online Questionnaire (Bilingual Edition-Italian and English). Edited by the Institute G. Toniolo of the Catholic University of the Sacred Heart of Milan. Città del Vaticano: Libreria Editrice Vaticana.

XV Ordinary General Assembly of the Synod of Bishops. 2018b. Final Document of the Pre-Synodal Youth Meeting (19-24 March 2018). Available online: http://press.vatican.va/content/salastampa/it/bollettino/pubblico/2018/ 03/24/0220/00482.html\#doc (accessed on 31 May 2020).

XV Ordinary General Assembly of the Synod of Bishops. 2018c. Final Document (27 October 2018). Available online: http://www.vatican.va/roman_curia/synod/documents/rc_synod_doc_20181027_doc-finalinstrumentum-xvassemblea-giovani_en.html (accessed on 31 May 2020).

XV Ordinary General Assembly of the Synod of Bishops. 2018d. Instrumentum Laboris (19 June 2018). Available online: http://www.vatican.va/roman_curia/synod/documents/rc_synod_doc_20180508_instrumentumxvassemblea-giovani_en.html (accessed on 31 May 2020).

(C) 2020 by the author. Licensee MDPI, Basel, Switzerland. This article is an open access article distributed under the terms and conditions of the Creative Commons Attribution (CC BY) license (http://creativecommons.org/licenses/by/4.0/). 